\title{
Transnational perspectives on black subjectivity
}

Co-ordinating Authors: ${ }^{1}$

Garth Stevens

University of the Witwatersrand

Deanne Bell

University of East London

Contributing Authors:

Christopher C. Sonn

Victoria University

Hugo Canham

University of the Witwatersrand

Ornette Clennon

Manchester Metropolitan University

\begin{abstract}
In this article, five black researchers bring their insights into conversation about meanings of blackness in contemporary Australia, Jamaica, South Africa, the United Kingdom and the United States of America. We critically interrogate blackness transnationally, but also within the historical contexts of our work and lived experiences. Situated within critical race studies, we draw on multiple theoretical frameworks that seek to preserve the complexity of blackness, its meanings and implications. We examine what it means to be made black by history and context, and explore the im/possibilities of transcending such subjectification. In so doing, we engage blackness and its relationality to whiteness; the historical, temporal and spatial dimensions of what it means to be black; the embodied, affective and psychical components of black subjectivity; and the continued marketization of blackness today. The article concludes by reflecting on the emancipatory promise of continued engagement with black subjectivity, but with critical reflexivity, so as to avoid the pitfalls of engaging blackness as a static and essentialised mode of subjectivity.
\end{abstract}

\section{Keywords}

Blackness, subjectivity, transnationalism, relationality, whiteness

\footnotetext{
${ }^{1}$ Corresponding authors:

Garth Stevens, Department of Psychology, University of the Witwatersrand, 1 Jan Smuts Avenue, Braamfontein 2000, Johannesburg, South Africa.

Email: Garth.Stevens@wits.ac.za

Deanne Bell, School of Psychology, University of East London, Water Lane, Stratford, London, E154LZ, United Kingdom.

Email: D.Bell@uel.ac.uk
} 


\section{Producing new knowledge about blackness and its effects:}

The effects of racialization on the subjectivity of Africans and the African diaspora have been inadequately examined in psychology's literature. Yet transnationally, psychologists are engaged in efforts to interrogate the ideology of race and racism and the conditions under which black people live. In 2015 Deanne developed a project titled Underneath Blackness to bring together social scientists to collectively deconstruct the legacies of blackness as it has been produced in light of coloniality. She imagined Underneath Blackness as a knowledge producing initiative in which the underside of blackness, that is, what has been silenced and repressed, can be articulated. The restoration of black subjectivity would, in this frame, be used as a resource to make the human experience of blackness more visible and contribute to raising consciousness about racial injustice.

Although many anti-black racism scholars, following Fanon, seek to contribute to postcolonial theory and decolonizing praxes, few utilize a depth psychological and/or psychoanalytic social approach to the study of blackness. Whilst recognizing this, the original aims of the Underneath Blackness project nevertheless yielded, in part, to a socio-cultural and psychosocial approach. The five black authors of this paper entered into a conversation about the meanings of blackness, as they understand it, in contemporary Australia, Jamaica, South Africa, the United Kingdom and the United States of America.

This paper follows the hosting of a roundtable at the ICCP 2016 by the five authors, creating a space for voices critical of the effects of coloniality to be heard within the field of community psychology. The roundtable dialogue highlighted the significance of being able to articulate experiences of black identity in an effort to understand social dynamics and contradictions inherent in being produced as racialized subjects, yet as human beings, able to exceed its dehumanizing constraints.

\section{A collective study:}

The origins of this project lie in the recognition that in psychology's literature, the underside of blackness is routinely overlooked.

Deanne: I had returned to Fanon's psychoanalytic theory of black traumatization to prepare for a roundtable I was facilitating at the Association for the Psychoanalysis of Culture \& Society Conference in the Fall of 2015. I was re-reading Black Skin, White 
Masks (Fanon, 1967) alongside Oliver's (2004) The Colonization of Psychic Space for a presentation titled "Bystanding Catastrophic Experience". I was grappling with a cascade of questions - how is trauma, as a consequence of state violence, experienced by the historically marginalized in the neoliberal world? What psychic mechanisms do we use to bystand, and therefore contribute to this injustice? Is witnessing an adequate response to the traumatization of black people? Can we elaborate on witnessing further? As I was thinking about the everyday ways in which black people undergo traumatization, I had a sense that what I was really questioning is what lies underneath the fabrication of blackness. What exists, in my body and other black bodies, that exceeds or transcends the excruciating experience of being made black in a world of whiteness? Talking with Christopher made me realize that this condition, of being dissatisfied with blackness whilst not yet having the language to articulate what would move us beyond it, is not peculiar to my experience and, may perhaps, be worthy of analysis. I shared my need to explore, contemporarily, with black people elsewhere, what blackness means beyond this suffering. As I listened to Christopher, I heard similar notes, and we agreed it was time to create a dialogue about the meaning before blackness, the meaning at the foundation of being made black, and experiences of blackness.

Christopher: Deanne and I had a conversation in 2015 at a community psychology conference in Lowell, MA. We were talking about our research and shared interest, including the article I wrote with Green and Matsebula (2007), partly titled, "Reviewing Whiteness". We discussed that the engagement with whiteness studies was in part a response to the fact that so many white students wanted to address issues of oppression, but often this was expressed as a telescopic philanthropy through the desire to help others, with little focus on dominance and challenging privilege. The turn to whiteness was in fact a way of shifting the gaze towards privilege and normativity. Deanne commented about the whiteness paper, but also in contrast, indicated that she wanted to examine blackness, its subjective and experiential meanings, and why it feels like a weight, like being stepped on, like being underneath something.

With hindsight, what this conversation implied was a duality of meanings within the question of what lies underneath blackness. Not only were Deanne and Christopher reflecting on the pernicious consequences of being made black in the world - what Fanon (1967) refers to a the 
yolk of historical and embodied racial epidermal schemata that are utilised by others to define us, and also by us in the service of self-definition - but they were also asking a set of questions about the transformative dimensions of blackness that may transcend this hegemonic construction of blackness.

As Garth, Ornette and Hugo were drawn into this initial conversation, we collectively generated questions to frame our ongoing deliberations - questions pertaining to blackness and its relationality to whiteness; the contingent nature of blackness in various historical, temporal and spatial contexts; the embodied, affective and psychical components of black subjectivity; the continued marketization of blackness within contemporary capitalism; and the im/possibilities of a transgressive blackness that extends beyond its hegemonic essentialisation.

\section{A community of praxis:}

As a collective, we have all either worked directly with each other, or initially had relationships that were characterised by one degree of separation. We have all also come to this project with specific contextual, social and personal histories as well as particular intellectual interests, but what does bind us, is that we are all black scholars and practitioners with an interest in critical race studies from different parts of the globe. As such we have become an organic community of praxis through these convergences.

For Hugo, a black South African psychologist, his interests have been directed towards the influence of racialization processes within organisational and social contexts, the transformation of these locales, and in how these racializing influences move through space and time.

\footnotetext{
Hugo: I have been preoccupied with how my black identity is articulated and recreated as a function of history and the different locations that I inhabit. I am pleased to be in conversation with peers from different parts of the world because I have wondered how other people experience themselves as racialized beings.
}

Ornette, based in the United Kingdom, is a composer, public-intellectual and critical race scholar-activist who is interested in the intersections between communities, culture, neoliberalism, social justice and race. As such, his praxis often traverses the formal academic, artistic and public domains. 
Ornette: In 2005, when I worked in the young offenders institution, HMP Werrington, on a music project, I first became alive to the idea "that what is often called the black soul is a white man's artefact" (Fanon, 1967, p. 6). Working with the predominantly young black men on their rap lyrics led me to question why they were so eager to promote themselves as 'real black men' and why this invariably involved them celebrating homophobia and misogyny. What was this in opposition to? I felt that it had to be more than just opposing 'authority' - leading me to a deeper exploration of blackness in the context of cultural production.

As another black South African psychologist and anti-racist scholar, Garth has had an enduring interest in exploring the systemically over-determined nature of racism, and consequently, how it continues to morph, accommodate and adjust to contextual circumstances, making it extremely tenacious as a form of differentiation, Othering and exploitation.

Garth: I have always been intrigued by racialized subjectivities and the ways that they are defined across temporal moments - as modes of capitulation to hegemonic subject constructions, as forms of cultural revitalisation and appropriation at other times, and ultimately also as forms of redefinition and radicalisation (Bulhan, 1985). Examining the conditions of possibility that allow for these variegated subject positions to gain traction has been important in my thinking about anti-racist praxis, but also to understand the obstinacy of racialization processes that continuously return in new iterations. Beyond this, I have been drawn to critical psychology's potential in uncovering the embodied, affective and psychical anchor points of racialized subjectivities - a middle ground between approaches that evacuate the subject in favour of structural understandings, and those that minimise structure in favour of subjective understandings of racialization processes.

Christopher has had an abiding interest in understanding responses to histories and systems of oppression, and also to challenge victim-blaming discourses and the absence of black voices within psychological writing. Importantly, Christopher is also positioned as a psychologist and member of the black South African diaspora, who now resides in Australia. 
Christopher: Underneath blackness resonated with me in many ways. I grew up in apartheid South Africa, in what was then a designated 'Coloured' community up until the mid-1980s. I understood what it meant to live in South Africa with this imposed identity label, the racialized hierarchy that governed our lives and got under our skin. Migrating to Australia, a country with a different racial formation (Omi \& Winant, 2015), and "white nation fantasy" (Hage, 1998) exemplified in the White Australia Policy, challenged the taken-for-granted ways in which I and other migrants from South Africa made sense of our histories and identities.

\section{Being-black-in-the-world:}

Our conversations have had many resonances with the intellectual threads that can be found in Du Bois' (1994) The Souls of Black Folk, Cesaire's (2000) Discourse on Colonialism, Fanon's (1961, 1967) The Wretched of the Earth and Black Skin, White Masks, Manganyi's (1973) Being-Black-in-the-World, and Mbembe's (2017) Critique of Black Reason, amongst others. In these texts, the key issue that arose for us was a non-essentialising approach to blackness, recognizing its multi-faceted and sometimes contradictory character - revealing what it means to live under the boot of whiteness and its global normativity, but also what may exist beyond such experiential, internalized and socially imposed forms of subjectivity.

Deanne's experiences highlight both the effects of racism on the black self, but also the apparent denialism that continues to pervade much of the public discourse, that consequently entrenches racialized asymmetries.

Deanne: Every time I feel black I feel annihilated. I do not feel beautiful nor do I feel the ability to change the forces that overwhelm my being. And I do not see social spaces being created in which we can acknowledge that juxtaposed against blackness is something else that is neither a capitulation to the deception of colour blindness nor the ascension to a post-racial condition, although, now that I think about it, it is on the road to utopia. This lack of critical public engagement with racism and its effects undergirds the hegemony of whiteness, solidifying its hold.

There are similar synergies with Christopher's contemplations, but while he recognizes the imposition of blackness, he also illuminates the resistant possibilities of the black subject. 
Christopher: In Australia, I was arguably no longer 'Coloured', but labelled black, as not from here, hailed into understandings of blackness circulating in Australia. Being constructed as black was mostly based on my skin, and I was seen as a non-white, ethnic Other. But, people do not necessarily take on these external constructions. Instead, we also have the capacity to carefully retrieve knowledge about our ancestors, and to use positive understandings of ourselves and our communities of origin (e.g. Black Consciousness) to reconstruct subjectivities constrained by oppression. In the new context, we are able to do this while also negotiating discourses that are used to signify us, and that give meaning to blackness in Australia.

Likewise for Ornette, in his work with young offenders on their music projects, there was a recognition and awareness of how racialized oppression manifests within their lives. However, there was also an emerging political consciousness, in which they understood the systemic nature of this oppression, and were considering utilising their blackness as a form of resistance.

Ornette: In their music, the young men wrote about how they thought that government oppression took the form of allowing the conditions of their estates (which they called "slums") to deteriorate to the extent that made drug dealing desirable (Werrington Album, 2007). Some of the young men were keen to ensure that their lived experiences and the siege mentalities (Bar-Tal, 2012) that they had developed were properly represented in the music that they were producing, so that their music definitely was not a case of "corporate globalization ... emptying out the subversive potential in culture" (Krishnaswarmy, 2002, p. 108).

While recognising the damaging effects of racism on black subjectivity and life, Garth also emphasises its non-static nature, surfacing how blackness can mutate and be re-crafted over time in the service of ongoing oppression, but simultaneously suggests that this opens up the possibilities for blackness to be a site of resistance and reclamation as well.

Garth: Even today, I have moments when I question my place in spaces that are dominated by whiteness; I am anxious about my competence as an academic in other instances; and I am sometimes ambivalent about my blackness inside the 'new' South Africa where my class position has enabled me to leave behind the structural and economic constraints associated with poor, working class, black South Africa. But I 
have also lived through the watershed of social and political transformation in South Africa, and so I think about our challenges with race in contemporary South Africa as one point on a continuum of ongoing struggles with a racialized history. This opens up the prospect of recognizing how various forms of imposed blackness and their attendant effects are protean, despite their historical rootedness. This provides an alternative to the presentism in the historiography of race in South Africa that suggests that the challenges of racism have simply remained static over time, and illuminates how forms of blackness have repeatedly shown dimensions of redefinition, discontinuity and resistance.

\section{Blackness and whiteness:}

A central question that emerged very early on within our conversations, was the extent to which blackness could exist outside of whiteness, or whether it is always relationally tethered to whiteness in the way that Fanon characterised it in his reflections on the Manichean worldview of coloniality (and by extension, postcoloniality) (Bulhan, 1985).

Hugo's account is quintessential of becoming aware of one's racialized status in the world - a moment in which our understanding of ourselves is fundamentally altered.

Hugo: Perhaps one of my earliest experiences of how I came to racial awareness was on crossing the 'border' from my homeland birthplace in the Transkei to Natal in apartheid South Africa. In this borderland space of heightened anxiety, our vehicle was stopped by white soldiers. My uncle, the driver of the vehicle, showed his papers and reconfigured his voice and body in ways that I would later recognise as what black men do to disarm their bodies. This was my earliest experience with whiteness as there were no white people in the rural part of the world where I was raised. This, and subsequent, experiences with white people habituated my body to respond to whiteness with marked discomfort, demobilized body language and feigned ease.

For Christopher, an awareness of our blackness and its maintenance is derived in relation to the existence of whiteness, but also through resistance to whiteness. However, he also notes the possibilities of transcending racialized subjectivities, through foregrounding a critical, common humanity, rather than relying on markers of difference. 
Christopher: At this point in the Australian context, meanings of blackness are tied to resisting whiteness for many groups who are constructed as Other. But for me personally, this piecing together is challenging and liberating work and involves coming to understand the various social, cultural and historical forces that combine to shape our subjectivities. Experiences of being black vary across context, time, and place. As Wright (2015) notes, blackness is not a matter of asking what, but about "when and where it is being imagined, defined, and performed and in what locations, both figurative and literal" (p. 3). Over the years and through my several returns to South Africa, it had become clear to me how whiteness had impacted upon my sense of self. Whenever I returned, I felt a sense of being with familiar sounds, faces, landscapes - I felt in place. But I also anticipated the white gaze, the weight of its sense of superiority. This changed. I remember returning a few years ago to participate in the Apartheid Archive Conference. Something had changed in me. I did not feel that white gaze, I felt comfortable in my skin, knowing that I knew whiteness as much as I had a new understanding of my/our history and my right to claim my voice and belonging in South Africa.

Garth argues that blackness as a relational construct, both historically and contemporarily, suggests that its uncoupling from whiteness may not be possible.

Garth: I have always thought that trying to conceive of blackness outside of a relational frame is premised on another kind of essentialism - one where we hope to retrieve a core of blackness that may have existed prior to the imposition and creation of the forms of blackness that are so integral to modes of racialized oppression within modernity. For me, this core does not exist as a form of blackness itself, and so is irretrievable. The relational origins of blackness as a binaried opposition to whiteness within the colonial matrix of power means that the two cannot be separated, even if this tethering is not always immediately visible. Blackness may be appropriated and redefined, but may not exist as a subjectivity that is unencumbered by whiteness. Other forms of post-racial subjectivity that extend beyond the black-white binary may indeed be possible, but such possibilities are historically and contextually contingent (Gilroy, 2010). Such a prospect is perhaps less conceivable within contexts like South Africa at present, where the economic and socio-cultural valence of race remains. 
Ornette extends on these understandings of blackness and its relationality to whiteness, by highlighting the reconfiguration of blackness and whiteness within modern capitalism.

Ornette: I began to view the music industry as part of the market, and by extension neoliberalism, that has a drive for profit. Elsewhere, (Clennon, 2016) I have made the arguments that the modern world system (i.e. early capitalism) was formed by the violent introduction of European nation-state building in 1492 (Dussel, 2000), where for the first time, labour was commoditised and later racialized (Quijano, 2000; Wallerstein, 2003). Disavowal between blackness and whiteness over the centuries has been transformed into market obscuration and segmentation via the mechanisms of 'market freedom' and 'individuality', in so doing, becoming more about market relations than race per se, where individuality becomes a market proxy for whiteness.

\section{The contingency of blackness:}

For Fanon (1967), the idea of historico-racial schema foregrounds the fact the black subjectivity is not initially a choice but one that we are born into when the history of racism is imprinted on us by virtue of our skin colour. Furthermore, black subjectivities move across contexts in different ways - they do not mean the same thing in different contexts. The black subject is thus always kept on the back foot, always guessing how he/she will be received in given contexts, potentially always displaying a neuroticism about his/her uncertain place in the world.

This burden of raced histories is what Hugo emphasises, indicating how even when one imagines, fantasizes or momentarily experiences freedom from them, that they are inescapable.

Hugo: As an individual, I have sufficient capital not to be too marginal. But I am aware of an oppressive weight that is both historical and political. I do not make my own history. I enter into the well-trodden space of the Department of Psychology at my workplace. This space is moulded by a colonial and apartheid history where access for me and raced subjects like me was forbidden. Through the kind of repetition and instantiation over time (Butler, 1988), the absence of black people began to foreclose an imagination that we could even enter the space as equal citizens who were not merely passing through. And so, some students and colleagues treat black bodies with suspicion, incredulity, or as invisible (Njovane, 2015). This stew of complexity is 
captured by Wetherell (2012, p. 22) when she observes that the "individual is a site in which multiple sources of activation and information about the body states, situations, past experiences... become woven together". When a black colleague recounts his experience of public humiliation by students in the classroom, I am affectively moved from a place of security to precarity.

Christopher comments on resistance, analysing how black subjectivity is also a sight of contestation and reclamation.

Christopher: Many migrant groups are constructed as black and Other, and as such, meanings of blackness are neither uniform, nor singular. While migrants are constructed as Other, typically against whiteness, so too are Aboriginal and Torres Strait Islander people. These groups have been subjected to colonialism, and through successive regimes of paternalistic and protectionist policies have been constructed as black and inferior, thereby seeking to regulate and, for many, remove their identities. Coloniality is expressed in everyday and institutionalized racism that continues to stifle their identities and subjectivities. But, Aboriginal and Torres Strait Islander groups are also resisting, surviving, decolonizing, articulating Aboriginal ways of knowing, doing and being, removing the term black from colonial discourse and redefining it as 'Blak' on their terms. The Aboriginal and Torres Strait Islander peoples' struggles for sovereignty resonates with struggles of black people in South Africa, and in many ways, my struggle.

The movement of the black subject across differing contexts is what Deanne surfaces. Who we are seen to be is determined by dominant assertions and constructions of what it means to be black in this context.

Deanne: Christopher and I share some similarities. He moved as a 'Coloured' man, from apartheid South Africa to Australia. I was born in middle-class circumstances in (post)colonial Jamaica. I am, in Jamaica, a 'browning' - a person of mixed race heritage whose access to the political economy opens up my sense of self, based on the infinite ways my 'brownness' ratchets me up the class hierarchy. Being a woman partially revokes race-class privilege but never fully negates it, in my experience. When I moved to the USA, to study and then work, this same body, now black, became a site of 
slippage. Gone was the meaning of my forefathers' (and mothers') social location, the intention of my knowledge, its understanding, the force of my love, the momentum of all that animates me. In its place sits depersonalisation. I mean nothing positive. The white cashier at the checkout releases coins into the air rather than soil her fingers by touching my palm.

But of course, even the nature and meanings of blackness within a given context are not themselves fixed. Garth's reflections on South African society are important in this regard.

Garth: For scholars of subjectivity, there is always the risk that we may overemphasise the experiential at the expense of the historical, but they are both equally important. The last 100 years in South Africa have seen dominant white constructions of blackness incrementally mobilised in the service of de-agrarianisation and the more deliberate development of capitalism, consolidated into hyper-exclusionary modes of social regulation, and moderated through processes of quasi-inclusion. Similarly, over this entire period, counter-hegemonic resistances to pejorative constructions of blackness were evident in forms of Black Nationalism, non-racialism, Black Consciousness, Pan-Africanism, anti-racism, etc. History warns us of the dangers and mutability of black subjectivity when being crafted in the service of privilege, but also reveals that it is a site of social contestation.

The importance of a deep reading of histories directed towards an understanding of black subjectivity and redefining it, is critical, as seen by Ornette within his music project.

Ornette: During the project, it became clear that it was the nature of popular culture and popular music in particular that gave us real clues as to how this indoctrination around black subjectivity was being carried out (Clennon, Bradley, Afuape \& Horgan, 2015). One of the inmates discovered the importance of knowing his cultural history and put special emphasis on the history of African chattel slavery. He very much connected slavery with the historical context of the institutional control and their implicit whiteness (he called them the "feds"), against which he was struggling. In his music the word "nigger" took on specific meaning and was used very sparingly only to denote the historicity of the word within a matrix of (historical) oppression, he felt and needed to express as young black man. I was really impressed with this level of 
awareness because he very much was ascribing to Gordon's (2016) view of “disposable life", where he explains that the modus operandi of neoliberalism is that of historical dislocation and community separation in order to form the 'individual' consumer. This view was emphasised when the same inmate said that some of his peers were only using the word to be contentious and to inject a perceived authenticity into their music ("keeping it real", so to speak) - very much a case of treating blackness as a market commodity (Collins, 2006).

\section{Affective practices and space:}

But blackness is not only historically, politically and structurally informed and determined. It is also experienced and enacted in an affectively embodied manner, is felt and expressed emotionally (see for example, Ahmed, 2004; Wetherell, 2015), and moves with us differently across space and time.

Deanne makes the point about the centrality of the body to the establishment and maintenance of the self.

Deanne: “Our corporeality” writes Barnaby Barratt (2013, p. 91) “is an inherent consciousness that grounds the possibility of all other-egological-formations of consciousness, and is thus the foundational nature of psyche". What are the possibilities of my being, our being (black, white, brown, yellow, Other) when whiteness does not foreclose on it? There exists multiple blacknesses. I have lived two, in Jamaica and the USA. As I talked with Christopher and he described the 'Blak' experience in indigenous Australia I wanted to grasp not only the socio-historic, political and cultural qualities of blackness, but also the boundedness of blackness on the self.

Hugo's account of his travels abroad and how blackness travels through time and space, reflect Said's (2000) ideas of exilic consciousness - the loss of or rupture with a familiar place or location, but the potential for being liberated and transgressive in moments away from that bounded, familiar location.

Hugo: When I travelled abroad, I looked forward to experiencing a world outside of the colonial and apartheid template. Having read Baldwin's categorization of the USA, 
I was not totally naïve though. In 1949, Baldwin (being influenced by the Harlem Renaissance) had described being black as follows: "I learned...that one was never looked at but was simply at the mercy of the reflexes the colour of one's skin caused in other people" (Baldwin, 1970, p. 77). But across the passage of time since Baldwin wrote, BET (Black Entertainment Television), movies, and Obama had convinced me that race was no longer a central issue in America. Perhaps, I should have anticipated what Ta-Nehisi Coates (2015) would later write when he reflected on the USA and the relationship between the police and the black body. On being stopped by police, he noted that "these officers had my body, could do with it whatever they pleased..." (p. 76). I should have held constant the idea that just as black men were historically hanged from plantation trees during the era of slavery, they continued to be hounded and shot at by police in the present. Cambridge Massachusetts was a revelation. I saw every black person. The intensity of the relationships that I built with the few black people that I knew was out of character for me. Coates (2015) describes the role of spaces affirming of one's blackness as life giving. For the first time I began attending events and socials deliberately organized around blackness. And yet, despite the spaces of mutual recognition I was totally disoriented. By October, two months into my stay in Cambridge, my body felt acutely out of place. And then I went to Harlem and regained my place in the world. Harlem was not home but my body felt at home. Here black bodies were a clear majority and were occupying space in a non-furtive, lived-in way. In my USA experience, there were differences and continuities with how I had experienced my blackness in South Africa. Space and history were fundamental in the creation and experience of my blackness. For Lefebvre (1991), space can be understood socially. We all situate ourselves in space. This requires centring ourselves in space, and measuring ourselves in relation to others within the space in terms of both an individual and public identity.

For Garth, the ways in which black bodies are mobilised and affective practices are enacted (Wetherell, 2015) are important for how an analytics of blackness can be furthered within new organic social movements.

Garth: The body is not only a site that is socially constructed, but also a site in which performances and practices are undertaken, and in which subjectivity itself is materialized (Butler, 1993). Codifications of the body have been and remain central to processes of alterity and marginalization. Fanon (1961), for example, suggested that 
within coloniality, black subjects are reduced to objects partly through collapsing the totality of subjectivity into the skin. Within the context of movements such as \#BlackLivesMatter, \#FeesMustFall and \#DecolonizeUniversities, deploying the primacy of the black body's 'pain' as a response to the bifurcation of the black soma and the black psyche may be understood as an organic response to reconstitute and reclaim these sequestered, obliterated and enigmatic psychic components. Embodied enactments and affective practices are frequently seen as ephemeral moments of psychological primordiality by those on the outside of these moments, but the body is a site of materialized psychic expression - your act is also you (Merleau-Ponty, 2013).

\section{Commodifying blackness:}

The historical relationship between racism and the development of capitalism is well established in the social scientific literature, but writers such as Gilroy (2010) caution us about how it is that such market forces continue to commoditise blackness. Where blackness reaffirmed itself physically, the market adjusted through the creation of personal hygiene, health and care products for blacks; where blacks agitated for economic parity, the market adjusted for this by introducing aspirational products to signal black social mobility; where blacks called for a recognition of their lived experiences, Blaxploitation as a cultural phenomenon emerged; etc.

Ornette suggests that this process continues to occur in instances where the trauma of blackness is itself commoditised within culture and the market.

Ornette: The young inmates resisted being reduced to 'black bodies' by the system. Borrowing from aspects of liberation psychology, our project worked hard to facilitate a re-interiorisation of the young men in terms of what their black maleness actually meant to them. Once they realised their connectedness (their social knowledge), they gradually rejected their market freedom to glorify violence in their music. They began to see it as a distinct negative and a block to their personal freedom. One inmate eloquently summed it up as follows: "It might've sounded good, people talking about killing parents and killing each other. It made the younger youth around react different. They started picking up guns... It was nothing to be proud of. I've been in jail for two years now. It was really a tough road for me. We're trying to get across to guys that gun crime is not the answer. In music you can chat about life, lifestyles and politics and 
things like that. You haven't got to talk about killing people." (Clennon, Bradley, Afuape, \& Horgan, 2015, p. 113).

\section{Some final considerations:}

If blackness as an experience can be fluid and contingent how then can we mobilize this motility in service of creating social relationships that affirm a sense of self, liberating people from the impositions of whiteness?

Christopher: With indigenous groups both in Western Australia and South East Australia, various communities of people of colour, and in some cases white colleagues, we are learning and producing new narratives about our own identities and subjectivities through creative means such as theatre, creative writing, storytelling, and photography. We need to be engaged with others across the global South who are also engaged in the dual task of deconstructing whiteness in our lives, while asserting and affirming the experiences of black communities in global contexts.

Garth: We have to be cognizant of how race is integral to forms of geopolitical development - uneven North-South relations, Islamophobia, anti-immigrant sentiment, etc. While transnational political solidarity will be important (Gilroy, 2000), black political solidarity that does not rely upon a notion of racial or identity essentialism will be as important (Shelby, 2005).

Deanne: If blackness, as Christopher following Wright (2015) noted earlier, is "not a matter of what, but where and how", then what can we learn about what is prior to and possibly post-blackness that exists in the (post)colonial? This curiosity, along with critiques of contemporary race studies may be generative as we think about the possibilities beyond blackness' harms.

This collective exploration into modes of blackness produced in various socio-cultural, historical and geographic locations underscores the complex nature of racialization, racism and its effects. It also reveals ways in which research dialogues can produce perspectives about experiences of blackness that may generate new understandings. It may be possible that collaborative reflexive engagements with critical race studies (as we have attempted to do here) 
can contribute to the development of critical race praxes that seek to build networks of solidarity in the struggle for a decolonized social world. 


\section{REFERENCES:}

Ahmed, S. (2004). The cultural politics of emotion. Edinburgh: Edinburgh University Press.

Baldwin, J. (1970). Notes of a native son. Corgi: London.

Bar-Tal, D. (2012). Siege mentality. In D.J. Christie (Ed.), The encyclopedia of peace psychology (Vol. 1, pp. 996-1000). Chichester: Wiley-Blackwell.

Barratt, B.B. (2013). The emergence of somatic psychology and bodymind therapy. London: Palgrave Macmillan.

Bulhan, H.A. (1985). Frantz Fanon and the psychology of oppression. New York: Plenum Press.

Butler J. (1988). Performative acts and gender constitution. An essay in phenomenology and feminist theory. Theatre Journal, 40(4), 519-531.

Butler, J. (1993). Bodies that matter: On the discursive limits of "sex". New York: Routledge.

Cesaire, A. (2000). Discourse on colonialism. New York: Monthly Review Press

Clennon, O.D. (2016). The black face of Eurocentrism: Uncovering globalisation. In O.D. Clennon (Ed.), International perspectives of multiculturalism: The ethical challenges (pp. 91-128). New York: Nova Science Publishers.

Clennon, O.D., Bradley, E., Afuape, T. \& Horgan, A. (2015). Keeping it real: Liberation through creativity and resistance. In T. Afuape \& G. Hughes (Eds.), Towards emotional well-being through liberation practices: A dialogical approach (pp. 103-113). London: Routledge.

Coates, T. (2015). Between the world and me. Spiegel \& Grau: New York.

Collins, P.H. (2006). New commodities, new consumers: Selling blackness in a global marketplace. Ethnicities, 6(3), 297-317.

Du Bois, W.E.B. (1994). The souls of black folk. New York: Dover Publications.

Dussel, E. (2000). Europe, modernity, and Eurocentrism. Nepantla, 1(3), 465-478.

Fanon, F. (1961). The wretched of the earth. New York: Grove Weidenfeld.

Fanon, F. (1967). Black skins, white masks. (R. Philcox, Trans.). New York: Grove.

Gilroy, P. (2000). Against race. Cambridge, MA: Belknap Press.

Gilroy, P. (2010). Darker than blue. Cambridge, MA: Belknap Press

Gordon, L. (2016, February 10). Disposable life. Retrieved from Vimeo: Histories of violence: https://vimeo.com/154827028

Green, M.J., Sonn, C.C. \& Matsebula, J. (2007). Reviewing whiteness: Theory, research, and possibilities. South African Journal of Psychology, 37(3), 389-419. 
Hage, G. (1998). White nation: Fantasies of white supremacy in a multicultural society. Sydney: NSW: Pluto Press.

Werrington Album. (2007). [mp3]. Stoke-on-Trent, Staffordshire: Make Some Noise. Available at http://youtu.be/EmZ57b8EI9Q and http://youtu.be/PI4fPL_69HE.

Krishnaswarmy, R. (2002). The criticism of culture and the culture of criticism at the intersection of postcolonialism and globalisation theory. Diacritics, 32(2), 106-126.

Lefebvre, H. (1991). The production of space. (D. Nicholson-Smith, Trans.). Blackwell Publishing: Malden.

Manganyi, N.C. (1973). Being-black-in-the-world. Johannesburg: Ravan Press.

Mbembe, A. (2017). Critique of black reason. Durham: Duke University Press.

Merleau-Ponty, M. (2013). Phenomenology of perception. London: Routledge.

Njovane, T. (2015). The violence beneath the veil of politeness. Reflections on race and power in the academy. In P. Tabensky \& S. Mathews (Eds.), Being at home: Race, institutional culture and transformation at South African higher education institutions (pp. 116-129). University of KwaZulu-Natal Press: Pietermaritzburg.

Oliver, K. (2004). The colonization of psychic space. Minneapolis, MN: University of Minnesota.

Omi, M. \& Winant, H. (2015). Racial formation in the United States. New York: Routledge.

Quijano, A. (2000). Coloniality of power and Eurocentrism in Latin America. International Sociology, 15(2), 215-232.

Shelby, T. (2005). We who are dark. Cambridge, MA: Belknap Press.

Wallerstein, I. (2003). Historical capitalism with capitalist civilization (11 ed.). London/New York: Verso.

Wetherell, M. (2015). Trends in the turn to affect: A social psychological critique. Body \& Society, 21(2), 139-166.

Wetherell, M. (2012). Affect and emotion. A new social science understanding. Sage: London. Wright, M. (2015). Physics of blackness: Beyond the middle passage epistemology. Minneapolis, MN: University of Minnesota Press. 